\title{
Anthocyanin Pigments of Wild and Seibel No. 13053 Grapes Harvested in Tokachi*t
}

\author{
Saburo Akuta, Hideaki Ohta, Yasunobu Sakane \\ and YUTAKA OSAJIMA \\ Department of Food Science and Technology, Faculty of Agriculture, Kyushu University, Fukuoka
}

(Received May. 12, 1977)

\begin{abstract}
Anthocyanin pigment contents in three strains (A,B and C) of wild grapes in Tokachi district and Seibel No. 13053 grapes were respectively $71.9,37.4,97.8$ and $64.3 \mathrm{mg}$ per $100 \mathrm{~g}$ of fresh weight in terms of delphinidin-3-monoglucoside.

From these grapes, 12 anthocyanins were isolated and identified as follows: 3-monoglucosides and 3,5-diglucosides of delphinidin, petunidin, malvidin and peonidin; delphinidin-3-monoglucoside and -3,5-diglucoside acylated with $p$-coumaric acid; peonidin-3,5-diglucoside and malvidin-3monoglucoside acylated with $p$-coumaric acid.

The species of wild grapes are discussed from the viewpoint of these pigment patterns mentioned above.
\end{abstract}

\section{Introduction}

Tokachi wine is popular in Japan. The species of wild grapes from which this wine is produced had been reported to belong to Vitis amurensis' ${ }^{1}$ that has only 3-monoglucoside pigments. Later on, IwANo' ${ }^{\text {a }}$ changed his opinion and claimed that this grapes belongs to $V$. coignetiae because of the presence of 3,5-diglucosides. As far as one can judge from his reports, he seems to have misidentified the anthocyanins and unknown RIBÉREAU-GAYON's papers.

RIBEREAU-GAYON ${ }^{31,4)}$ reported on the distribution of anthocyanins among different species of the genus Vitis and its application for chemotaxonomy. He proved the presence of 3 -glucosides of malvidin, petunidin and peonidin, and 3,5-diglucosides of malvidin and peonidin, and the absence of acylated anthocyanins in $V$. amurensis. However, the pigment pattern of $V$. coignetiae was not referred to in his reports.

In this paper, the results of investigation of the anthocyanin pigments of wild grapes in Tokachi district and Seibel No. 13053 are reported, with a discus sion of the species of wild grapes.

\section{Materials and Methods}

Grapes: Ripe grapes $(3 \mathrm{~kg}$ ) of three wild strains (A, B and C) and Seibel No. 13053 (S13053) were obtained in autumn, 1975, from the vineyard of Tokachi-Ikeda Viticulture and Enology Experiment Station in Hokkaido.

Determination of soluble sugar and acid contents: Grape juice was prepared by cold pressing and then centrifuged at $10,000 \mathrm{rpm}$ for $20 \mathrm{~min}$ at $0^{\circ} \mathrm{C}$. The soluble sugar content !n the grape juice $(100 \mathrm{~m} l)$ was determined by a modified Somogyi method ${ }^{5}$, calculated in terms of glucose. Acid was titrated with alkali $(0.1 N \mathrm{NaOH})$ up to $\mathrm{pH} 8.2$ with Methorom Potentiography E436, calculated in terms of tartaric acid.

Preparation of pigment solution: Each $200 \mathrm{~g}$ of grapes was macerated in a Waring blendor with $500 \mathrm{~m} l$ of $0.1 \% \mathrm{HCl}$-methanol solution for $5 \mathrm{~min}$. The mixture was filtered in a Buchner funnel throught filter paper. The process was repeated five more times with the same solvent until filtrates became

$\dagger$ Studies on Anthocyanin Pigments in Fruits Harvested in Japan (Part 7)

* Presented in part of the $23 \mathrm{rd}$ Annual Meeting of the Japanese Society of Food Science and Technology, Tokyo, Japan, June 1976 
colorless. After combining those extracts, crude anthocyanin solution was prepared by the basic lead acetate method ${ }^{6}$.

Paper chromatography (PPC) and thin layer chromatography (TLC): The solvent systems for PPC and TLC were as follows. iBAW, isobutanol-acetic acid-water $(8: 2: 3, \mathrm{v} / \mathrm{v})$; BAW, $n$-butanol-acetic acid-water $(4: 1: 5$, $\mathrm{v} / \mathrm{v}) ; 1 \% \mathrm{HCl}$, conc. $\mathrm{HCl}-$ water $(3: 97, \mathrm{v} / \mathrm{v})$; Forestal, acetic acid-water-conc. $\mathrm{HCl}$ (30:10: $3, \mathrm{v} / \mathrm{v})$; $\mathrm{FHW}$, formic acid-conc. $\mathrm{HCl}$-water $(5: 2: 3, \mathrm{v} / \mathrm{v})$; $\mathrm{BHW}, n$-butanol-conc. $\mathrm{HCl}$ water $(7: 2: 5, \mathrm{v} / \mathrm{v})$; BPW, $n$-butanol-pyridinewater $(6: 3: 1, v / v) ; 2 \% \mathrm{AcOH}$, acetic acidwater $(2: 98, v / v)$, and BzAW, benzene-acetic acid-water $(2: 2: 1, v / v)$.

Toyo No. 50 filter paper $(40 \times 40 \mathrm{~cm})$ was used for separation of pigments with iBAW solvent system. Purification of individual anthocyanins (IAcy) was carried out by the same method except for paper size $(20 \times 20$ $\mathrm{cm}$, ascending manner) with the following solvent system; AHW, BAW and $1 \% \mathrm{HCl}$. Two-dimensional chromatography was done on a thin layer (Avicel cellulose) plate $(20 \times$ $20 \mathrm{~cm}$ ) with $\mathrm{iBAW}$ as the first solvent and AHW as the second.

Identification of LAcy: Identification of anthocyanin was carried out by usual methods (comparison of color and $R f$ values, absorption spectroscopy, partial acid hydrolysis ${ }^{7,8)}$, alkaline degradation of aglycone ${ }^{18}$ and other chromatographic techniques).

Determination of anthocyanin content in grapes: Crude anthocyanin pigments from $20 \mathrm{~g}$ of grapes were treated with basic lead acetate reagent $^{6)}$ and diluted to $250 \mathrm{ml}$ with $0.1 \% \mathrm{HCl}$ -methanol solution. Antho cyanin content was determined by measuring absorbance at 543 $\mathrm{nm}\left(\lambda_{\max }\right)$, calculated in terms of delphinidin3-monoglucoside; $\varepsilon_{543 \mathrm{~nm}}^{0.1 \% \mathrm{HCl}-\mathrm{MeOH}}=2.9 \times 10^{4}$.

IAcy contents were analyzed in accordance with the previous reports ${ }^{78}$ ).

\section{Results and Discussion}

\section{Soluble sugar and acid}

Contents in juices A, B, C and S-13053 were respectively as follows: sugar in terms of glucose: $11.40,10.60,18.50$ and $12.45 \mathrm{~g} / 100$ $\mathrm{ml}$; acid in terms of tartaric acid: 2.94, 2.98, 2.35 and $1.44 \mathrm{~g} / 100 \mathrm{ml}$; sugar/acid ratio: $3.88,3.56,7.87$ and 8.65 .

S-13053 had a high sugar/acid ratio suitable for grape juice. A and B had larger acid quantities than the others. $C$ was the most suitable for winemaking because of its large content of sugar.

2. Two-dimensional TLC of anthocyanins

Two-dimensional TLC from three wild and S-13053 grapes indicated the presence of 12 anthocyanins shown in Fig. 1.

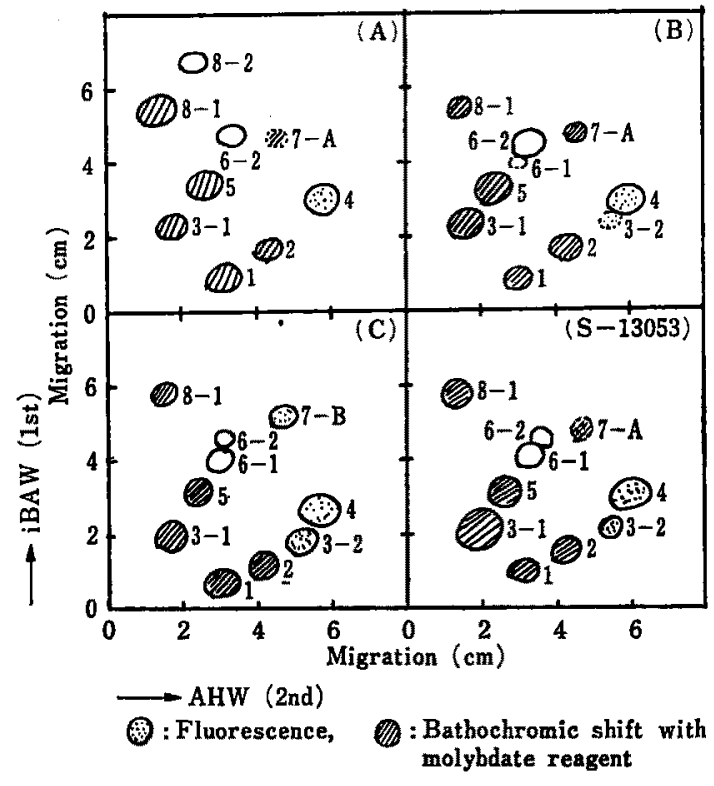

Fig. 1 Two-dimensional thin layer chromatograms of anthocyanins in grapes $(A, B$, $C$ and Seibel No. 13053)

Pigments Nos. 1 and $3-1$ were the most abundant pigments with bluish purple colors. Pigments Nos. $3-2,4$ and $7-B$ proved to be 3,5-diglucoside pigments, since they emitted fluorescence under ultra-violet radiation.

Pigments Nos. 1, 2, 3-1, 5, 7-A and 8-1 turned blue after being sprayed with molybdate reagent, which provides information on the presence of ortho hydroxylation in the B-ring.

3. Chromatographic properties of IAcy

The $R f$ values in four solvent systems, and colors under visible and u.v. light are given in Table 1. 
Table 1 Comparison of $\mathrm{Rf}$ values and colors of individual anthocyanins in grapes

\begin{tabular}{|c|c|c|c|c|c|c|c|}
\hline \multirow{2}{*}{$\begin{array}{c}\text { Pigment } \\
\text { No. }\end{array}$} & \multicolumn{4}{|c|}{$R f$ values $(\times 100)$ at $23^{\circ} \mathrm{C}$} & \multicolumn{3}{|c|}{ Colors* in } \\
\hline & IBAW & BAW & AHW & $1 \% \mathrm{HCl}$ & visible light & $(\mathrm{H}-\mathrm{V}-\mathrm{C})$ & u.v. lignt \\
\hline 1 & 9 & 16 & 30 & 8 & Pale purple & $(21-18-3)$ & Bright purple \\
\hline 2 & 15 & 24 & 32 & 8 & Pale purple & $(22-18-3)$ & Bright purple \\
\hline $3-1$ & 19 & 25 & 18 & 3 & Pale purple & $(20-18-3)$ & Dull purple \\
\hline $3-2$ & 20 & 30 & 40 & 12 & Light red purple & $(23-16-6)$ & Fluor. purple \\
\hline 4 & 25 & 35 & 43 & 15 & Dull red purple & $(2-16-5)$ & Fluor pink \\
\hline $\mathbf{5}$ & 28 & 34 & 22 & 4 & Pale purple & $(21-18-4)$ & Dull purple \\
\hline $6-1$ & 35 & 38 & 28 & 6 & Red purple & $(23-15-6)$ & Dull purple \\
\hline $6-2$ & 38 & 39 & 33 & 9 & Light red & $(1-17-6)$ & Dull purplish red \\
\hline $7-A$ & 40 & 41 & 31 & 12 & Pale purple & $(21-18-4)$ & Bright purple \\
\hline 7-B & 42 & 41 & 42 & 11 & Light red & $(1-17-6)$ & Fluor. pink \\
\hline $8-1$ & 48 & 51 & 10 & 3 & Pale purple & $(20-18-4)$ & Dull purple \\
\hline $8-2$ & 50 & 52 & 21 & 3 & Light red purple & $(22-17-4)$ & Light purple \\
\hline
\end{tabular}

Fluor.: Fluorescent

*: Classified in accordance with "Guide to Color Standard," (1951)12).

The comparison of these data with previous reports $^{7,8,10,11)}$ indicated that pigments Nos. $1,2,3-1,3-2,4,5,6-1$ and $6-2$ were delphinidin -3,5-diglucoside (Dl-3,5DG, abbreviation in Table 4), Pt-3,5DG, DI-3G, Mv-3,5 DG, Pn3,5DG, Pt-3G, Mv-3G and Pn-3G*, respectively. Pigments Nos. 7 and 8 seemed to be acylated anthocyanins, since they showed larger $R f$ values in organic solvent systems (iBAW and BAW) and smaller $R f$ values in aqueous solvent system (AHW).

\section{Spectral properties of IAcy}

The absorption maxima, the ratios of the absorbance at $440 \mathrm{~nm}$ to the maxima of IAcy and the adding effect of aluminium chloride on these spectra are listed in Table 2.

The presence of shoulder peaks (about 308 $\mathrm{nm}$ ) in the spectra of pigments Nos. 7-A, 7-B, 8-1 and 8-2 showed that these pigments were acylated anthocyanins.

The absorbance ratio ( $\mathrm{E} 440 / \mathrm{E}_{\max }$ ) can be used for differentiating 3-monoglucoside (3G) from 3, 5-diglucoside (3,5DG). Therefore, pigments Nos. 1, 2, 3-2, 4, 7-A and 7-B were found to be $3,5 \mathrm{DG}$ pigments because of their smaller values than 18 . The other pigments proved to be $3 \mathrm{G}$ pigments.

The absorption peak (pigments Nos. 1,2, $3-1,5,7-\mathrm{A}$ and $8-1$ ) shifted when aluminium chloride was added as a chelating agent.

Table 2 The absorption spectra of individual anthocyanins in grapes

\begin{tabular}{|c|c|c|c|c|c|}
\hline \multirow{2}{*}{$\frac{\text { Pigment No. }}{1}$} & \multicolumn{3}{|c|}{$\lambda \max$ in $0.01 \% \mathrm{HCl}-\mathrm{MeOH}(\mathrm{nm})$} & \multicolumn{2}{|c|}{ E 440/Evis.max $(\%)$ Shift with AlCls } \\
\hline & 280 & & 535 & 13 & + \\
\hline 2 & 279 & & 533 & 11 & + \\
\hline $3-1$ & 275 & & 536 & 20 & + \\
\hline $3-2$ & 280 & & 533 & 12 & - \\
\hline 4 & 280 & & 523 & 13 & - \\
\hline 5 & 278 & & 534 & 20 & + \\
\hline $6-1$ & 280 & & 535 & 27 & - \\
\hline $6-2$ & 280 & & 525 & 20 & - \\
\hline $7-\mathbf{A}$ & 283 & $308 \mathrm{sh}$ & 534 & 11 & + \\
\hline $7-B$ & 280 & $308 \mathrm{sh}$ & 526 & 11 & - \\
\hline $8-1$ & 280 & $308 \mathrm{sh}$ & 538 & 25 & + \\
\hline $8-2$ & 280 & $308 \mathrm{sh}$ & 538 & 16 & - \\
\hline
\end{tabular}

sh: Shoulder

*: Abbreviations are referred to in Table 4. 
This indicates the presence of ortho hydroxy groups in the B-ring.

5. Partial acid hydrolysis

The chromatograms of the hydrolysis products developed with BHW and AHW solvent systems indicated that pigments Nos. 3-1, 5, 6-1 and 6-2 were 3-glucoside pigments which yielded two spots and that Nos. 1,2, 3-2 and 4 were 3,5-diglucoside pigments which yielded four spots. Pigments Nos. 7-A and 7-B gave five spots on each chromatogram, and Nos. 8-1 and 8-2 gave three spots.

6. Aglycones, sugar moieties and acyl moieties

The aglycones were identified by their $R f$ values and colors on the paper as follows: pigments Nos. $1,3-1,7-\mathrm{A}$ and $8-1$ were delphinidin ( $R f ; 0.33$ in forestal, 0.15 in FHW, dull purple), Nos. 2 and 5 were petunidin ( $R f ; 0.47$ in forestal, 0.22 in FHW, purple), 0.59 in forestal, 0.26 in FHW, red purple), and Nos. 4, 6-2 and 7-B were peonidin ( $R f$; 0.65 in forestal, 0.33 in $\mathrm{FHW}$, pink).

The sugars in IAcy were determined by PPC of acid hydrolysis products. Glucose ( $R f ; 0.28$ and 0.34 in BAW and $\mathrm{BPW}$, respectively) was the only sugar isolated from IAcy.

Acid hydrolysis ${ }^{61,14}$ can remove acyl groups from the anthocyanin. The acyl moieties iu pigments Nos. 7-A, 7-B, 8-1 and 8-2 were identified to be $p$-coumaric acid $(R f ; 0.92$ in $\mathrm{BAW}, 0.67$ in $\mathrm{BzAW}$ and 0.44 in $2 \% \mathrm{AcOH}$, orange color after spraying with diazotized $p$-nitro-aniline reagent).

7. Alkaline degradation of the aglycone

The results of alkaline degradation of aglycones (except Nos. 7-A, 7-B, 8-1 and 8-2) are given in Table 3 , which shows that aglycones were delphinidin (Nos. 1 and 3-1), petunidin (Nos. 2 and 5), malvidin (Nos. 32 and 6-1) and peonidin (Nos. 4 and 6-2).

8. Conclusion

On the basis of the above observation, the anthocyanins in three wild and S-13053 grapes were identified as listed in Table 4 . The amounts of IAcy are given in Table 5 . Besides, total anthocyanin contents were calculated in terms of D1-3G. It was concluded that $\mathrm{C}$ grape was the most suitable fruit for winemaking because of its high contents of sugar and pigments.

These grapes were characterized as follows; (1) the presence of acylated delphinidin glucosides was first found in grapes harvested in Japan and (2) delphinidin and petunidin contents were greater than malvidin and peonidin contents that were detected as the major pigments in previous reports ${ }^{7,81,101,111}$.

Table $3 R f$ values and color characteristics of alkaline degradation products of individual anthocyanidins in grapes (except phloroglucinol)

\begin{tabular}{cccl}
\hline \multirow{2}{*}{ Pigment No, } & \multicolumn{2}{c}{$R f$ values $(\times 100)$} & Color with DPNA*+NH 8 \\
\cline { 2 - 4 } & BAW & $2 \%$ AcOH & Gray brown \\
\hline 1 & 67 & 42 & Red purple \\
2 & 77 & 50 & Gray brown \\
$3-1$ & 67 & 42 & Blue \\
$3-2$ & 87 & 57 & Purple \\
4 & 80 & 61 & Red purple \\
5 & 78 & 50 & Blue \\
$6-1$ & 87 & 57 & Purple \\
$6-2$ & 80 & 60 & Gray brown \\
Gallic acid & 67 & 42 & Purple \\
Vanillic acid & 80 & 61 & Blue \\
Syringic acid & 87 & 57 & Dull purple \\
Protocatechuic acis & 81 & 54 & Gray brown \\
p-Coumaric acid & 90 & 43 &
\end{tabular}

*: Sprayed with diazotized $p$-nitroaniline reagent 
Table 4 Identification of the anthocyanins in grapes (A, B, C and Seibel No. 13053)

\begin{tabular}{|c|c|c|}
\hline Pigment No. & Identification & Abbreviation \\
\hline 1 & Delphinidin-3,5-diglucoside & (D1-3,5DG) \\
\hline 2 & Petunidin-3,5-diglucoside & $(\mathrm{Pt}-3,5 \mathrm{DG})$ \\
\hline $3-1$ & Delphinidin-3-monoglucoside & $(\mathrm{DI}-3 \mathrm{G})$ \\
\hline 3-2 & Malvidin-3,5-diglucoside & $(\mathrm{Mv}-3,5 \mathrm{DG})$ \\
\hline 4 & Peonidin-3,5-diglucoside & $\left(P_{n}-3,5 D G\right)$ \\
\hline 5 & Petunidin-3-monoglucoside & $\left(P_{t-3 G)}\right.$ \\
\hline $6-1$ & Malvidin-3-monoglucoside & $(\mathrm{Mv}-3 \mathrm{~F})$ \\
\hline $6-2$ & Peonidin-3-monoglucoside & $(\mathrm{Pn}-3 \mathrm{G})$ \\
\hline $7-\mathrm{A}$ & Delphinidin-3,5-diglucoside acylated with $p$-coumaric acid & (D1-3,5DG-Cm) \\
\hline $7-B$ & Peonidin-3.5-diglucoside acylated with $p$-coumaric acid & $\left(P_{n-3}, 5 D G-C m\right)$ \\
\hline $8-1$ & Delphinidin-3-monoglucnside acylated with $p$-coumaric acid & $(\mathrm{D} 1-3 \mathrm{D} \mathrm{r}-\mathrm{Cm})$ \\
\hline $8-2$ & Malvidin-3-monoglucoside acylated with $p$-coumaric acid & $(\mathrm{Mv}-3 \mathrm{G}-\mathrm{Cm})$ \\
\hline
\end{tabular}

Table 5 Anthocyanin content of fresh grapes (A, B, C and Seibel No. 13053)

\begin{tabular}{|c|c|c|c|c|c|c|c|c|c|c|c|c|c|}
\hline \multirow{2}{*}{\multicolumn{2}{|c|}{$\begin{array}{c}\text { Acy* } \\
\mathrm{mg} / 100 \mathrm{~g} \text { berry }\end{array}$}} & \multicolumn{2}{|c|}{$C y^{* *}$} & \multicolumn{2}{|c|}{$\mathrm{Pn}^{* *}$} & \multicolumn{2}{|c|}{$\mathrm{D} 1 * *$} & \multicolumn{2}{|c|}{$\mathrm{Pt}^{* *}$} & \multicolumn{2}{|c|}{$M v^{* *}$} & \multicolumn{2}{|c|}{ T. acylated ${ }^{* *}$} \\
\hline & & \multirow{2}{*}{$\begin{array}{r}3 \\
- \\
\end{array}$} & \multirow{2}{*}{$\frac{3.5}{-}$} & \multirow{2}{*}{$\begin{array}{r}3 \\
8\end{array}$} & \multirow{2}{*}{$\frac{3.5}{14}$} & \multirow{2}{*}{$\frac{3}{22}$} & \multirow{2}{*}{$\frac{3,5}{12}$} & \multirow{2}{*}{$\begin{array}{r}3 \\
14\end{array}$} & \multirow{2}{*}{$\frac{3.5}{8}$} & \multirow{2}{*}{$\frac{3}{2}$} & \multirow{2}{*}{$\begin{array}{r}3.5 \\
-\end{array}$} & \multirow{2}{*}{$\begin{array}{r}3 \\
20\end{array}$} & \multirow{2}{*}{$\frac{3,5}{\text { trace }}$} \\
\hline $\mathbf{A}$ & 71.9 & & & & & & & & & & & & \\
\hline B & 37.4 & - & - & 10 & 14 & 29 & 14 & 13 & 10 & 2 & 3 & 3 & 2 \\
\hline $\mathrm{C}$ & 97.8 & - & - & 7 & 13 & 22 & 12 & 12 & 11 & 8 & 10 & 3 & 2 \\
\hline$S-13053$ & 64.3 & - & - & 11 & 12 & 21 & 15 & 11 & 10 & 6 & 12 & 2 & trace \\
\hline \multicolumn{2}{|c|}{ V. amurensis } & - & - & 13 & 15 & - & - & 5 & - & 27 & 40 & - & - \\
\hline \multicolumn{2}{|c|}{$V \cdot$ coignetigen $^{a)}$} & - & + & + & + & + & - & + & - & + & + & - & - \\
\hline
\end{tabular}

* : Anthocyanin content, **: Cy: cyanidin, Pn: peonidin, D1: delphinidin, Pt: petunidin,

Mv: malvidin, $3: 3$-monoglucoside, 3,5:3.5-diglucoside, T. acylated: rotal acylated pigments.

RIBEREAU-GAYON ${ }^{8,1,}$ represented that $V$. amurensis was characterized by the absence of acylated anthocyanin, and cyanidin-and delphinidi-glucocides. IWANO ${ }^{1,21}$ seems to have not identified to acylated antocyanin and there were many interrogation points on his methods and results. Our results were not in accord with either the pigment patterns of $V$. amurensis ${ }^{31,4)}$ or of $V$. coignetiae ${ }^{2)}$. Consequently, we presume that this grapes belong to a variety of $V$. amurensis, probably V. amurensis Rupr. var. glabrescens NAKAI. ${ }^{151}$

Acknowledgement: The authors are grateful to Mr. Yoshio ITo, the head of Tokachi-Ikeda Viticulture Enology Experiment Station for his generous offer of Seibel No. 13053 grapes and three strains of wild grapes. They also thank Mr. ABdur Razzaque for reading this manuscript.

\section{References}

1) Iwano, S.: Presented in the Annual Meeting of the Japanese Society of Horticulture Science, Tokyo, Japan, April 1966, Abstracts, p. 89.

2) Iw ano, S.: Personal communication (1968).

3) Ribereau-Gayon, P.: "The Chemistry of Red Color," in "Chemistry of Winemaking," ed. by A.D. WeBs, American Chemical Society, p. 58 (1974).

4) RibereaU-Gayon, P.: Recherches sur les Anthocyannes des Végétaux. Application au Genre Vitis," Librairie General Enseignement, Paris, p. 114 (1959).

5) KoBayashi, T. and TABuch, T.: J. Japanese Society of Agricultural Chemistry, 28, 171 (1953).

9) Ohta, H., Osajima, Y., Sawamura, M., NakaMURA, H. and AKUTA, S.: J. Food Sci. Technol., Tokyo, 23, 345 (1976).

7) Akuta, S. and Matsudomi, N.: J. Food Sci. Technol., Tokyo, 23, 101 (1976).

8) idem: ibid, 23, 108 (1976).

9) Asen, S., Stuart, N.W., Siegrlman, H.W.: 
Proc. Am. Soc. Hort. Sci., 73, 495 (1959).

10) Matudom, N., YamamuRA, M., Kobayashi, K., Oнта, H., Axuta, S.: J. Food Sci. Technol., Tokyo, 24, 279 (1977).

11) Matsudom, N., Yamamura, M., Ohta, H., Osajima, Y., Akuta, S.: J. Food Sci. Technol., Tokyo 42, 342 (1977).

12) Nippon Shikisal Kankyusho: "Guide to Color Standard," Nippon Shikisai Kenkyusho, Japan,
(1951).

13) LuH, B.S., Stachowigz, K., Hsia, G.L.: J. Food Sci., 30, 300 (1965).

14) Sakellariades, H.C. and LuH, B.S.: $J$ Food Sci., 39, 329 (1974).

(Received May. 12, 1977)

15) Murakoshi, M.: Naigai Shokubutsu Daizukan, Vol. 5, p. 33, Shokubutsu Genshoku Kankokai, Tokyo (1933).

十勝産・野生ブドウおよび Seibel No. 13053 ブドウのアントシアニン色素

芥田三郎・太田英明*・坂根康伸*・筬島 豊*

(*九州大学㕮学部食柤化学工学科)

十勝地方の野生ブドウ 3 系統(A，B およびC) と Seibel No. 13053 プドゥ中のフントシフニン色素含量は, デル フィニジンー3-モノグルコシドとして, 各ふ, 71.9,37.4, 97.8 および $64.3 \mathrm{mg} / 100 \mathrm{~g}$ 新鮮重であった。

12 コのフントシフニン色素が単離され，以下のように 同定された。デルフィニジン, ペチュニジン, 、ルビジ ン, ペオニジンの 3-モノグルコシド拉よ゙ 3,5-ジグル コシド，p-クマル酸によってアシル化されたデルフィ二 ジン-3-モノグルコシドと-3,5-ジグルコシド, そして pークマル酸によってアシル化されたベオニジンー3,5-ジ グルコシドとマルビジンー3-モ/グルコシド。

上述の色素バターンから，本野生ブドウの種属する種 について論議された。

(昭和 52 年 5 月 12 日受理) 